\title{
Linfangioma cervical: manejo terapéutico con OK-432 (Picibanil)
}

\section{Cervical lymphangioma: therapeutic management with $0 \mathrm{~K}-432$ (Picibanil)}

\author{
E. Valle Rodríguez', V. Villanueva San Vicente², M.A. Rodríguez González², D. Segarra Fenoll², \\ M.J. García Mateos', S. Méndez-Trujillo 3
}

Resumen: Introducción: El linfangioma es una malformación del sistema linfático. El abordaje clásico ha sido la cirugía. El OK-432 (Picibanil) tiene acción esclerosante y se está utilizando cómo primer escalón terapéutico. El objetivo es aportar un nuevo caso de linfangioma tratado con OK-432 y hacer una revisión de la literatura.

Material y método: Aportamos un varón de 16 años con un linfangioma cervical macroquístico de $10 \times 6 \mathrm{~cm}$ tratado con una dosis de OK-432.

Resultados: A las 16 semanas del tratamiento, el tamaño del linfangioma era de $6 \times 2 \mathrm{~cm}$, siendo clínicamente inapreciable.

Discusión: El tratamiento con OK-432 tiene una alta tasa de curación, con una baja tasa de recidiva y una fibrosis circunscrita a la lesión. En relación con la cirugía, se evitan cicatrices y posibles lesiones de estructuras vitales.

Palabras clave: Linfangioma; Esclerosis; OK-432; Picibanil.

Recibido: 01.02.07

Aceptado: 17.09.07

\begin{abstract}
Introduction: Lymphangioma is a malformation of the lymphatic system. The classic approach is surgery. OK-432 (Picibanil) has sclerosing action and is being used as the first therapeutic step. The objective was to report a new case of lymphangioma treated with OK-432 and to review the literature.

Material and method: We report the case of a 16-year-old man with a 10x6-cm macrocystic cervical lymphangioma treated with a dose of OK-432.

Results: At 16 weeks of treatment, the size of the lymphangioma was $6 \times 2 \mathrm{~cm}$ and it was clinically unappreciable.

Discussion: OK-432 treatment has a high cure rate, low recurrence rate, and fibrosis circumscribed to the lesion. Compared to surgery, scars and possible harm to vital structures are avoided.
\end{abstract}

Key words: Lymphangioma; Sclerosis; OK-432; Picibanil.

\footnotetext{
1 Médico Residente.

2 Médico Adjunto.

3 Jefe de Servicio. Servicio de Cirugía Oral y Maxilofacial.

Hospital Virgen de la Arrixaca, Murcia.
}

\section{Correspondencia:}

Ekaitz Valle Rodríguez

Servicio de Cirugía Oral y Maxilofacial.

Hospital Virgen del Arrixaca

Ctra. Cartagena s/n (El Palmar), Murcia, España.

Email: ekaitzvalle@hotmail.com 


\section{Introducción}

El linfangioma es una malformación congénita y en algunas ocasiones adquirida tras acción traumática, infecciosa, yatrogénica o neoplásica, del sistema linfático.1,2 Se presenta como una masa benigna, de crecimiento lento y consistencia blanda, habitualmente asintomática, que puede causar problemas estéticos y funcionales tales como disfagia y disnea, sobre todo cuando aumentan rápidamente su tamaño por infección, o sangrado cuando coexiste con lesiones vasculares. No hay diferencias en cuanto al sexo. ${ }^{1,2,4-6} \mathrm{La}$ morbi-mortalidad está relacionada con el tamaño y la edad temprana del paciente. ${ }^{2}$ Hasta el $90 \%$ de ellos se diagnostican antes de los 2 años de edad y hasta el $50 \%$ en el momento del nacimiento. ${ }^{4}$ La localización más frecuente del linfangioma es la región cervical (75\%) y dentro de ella el triangulo posterior.? Le siguen otras como: región submentoniana, lengua, orofaringe y celda parotidea.

El linfangioma se clasifica en capilar, cavernoso y quístico, pudiendo coexistir diferentes formas en un mismo linfangioma. La localización, estructura y consistencia de los tejidos circundantes pueden condicionar los diferentes tipos histológicos. El linfangioma quístico está compuesto de quistes delimitados por una capa de endotelio y se presenta en áreas de tejido laxo y abundantes fascias como por ejemplo la región cervical. 1,2 Se puede subclasificar a su vez según el tamaño. Definimos macroquístico como lesión con quistes mayores de $2 \mathrm{~cm}$ y microquístico como lesión con quistes menores de $2 \mathrm{~cm}$. Existen linfangiomas mixtos de predominio macro o microquístico.

Anatómicamente son cavidades llenas de líquido linfático, delimitado por endotelio vascular, conectado con el sistema linfático periférico como resultado de una embriogénesis errónea. ${ }^{8}$

El diagnóstico, se basa en la clínica y en técnicas de imagen, siendo la RM la que nos da mayor definición, extensión de la lesión y visión de las estructuras vecinas. La eco-doppler es útil para diferenciar los linfangiomas de las malformaciones vasculares o mixtas, por la existencia de flujo vascular. La RM puede no distinguir el linfangioma de las malformaciones venosas, por lo que en estos casos la utilización de contrastes puede ayudar al diagnóstico. ${ }^{4} \mathrm{La}$ PAAF puede se utilizada también como método diagnóstico. ${ }^{1}$ El diagnóstico diferencial incluye el quiste branquial, quiste tirogloso, laringocele, masa tiroidea, lipoma y malformaciones vasculares. El tratamiento puede ser mediante escisión quirúrgica o bien mediante esclerosis de la lesión por acción de agentes esclerosantes. Entre ellos destaca el OK-432, también llamado Picibanil, que es un compuesto liofilizado de baja virulencia, substraido de la bacteria del streptococcus pyogenes del grupo A de origen humano. Ha sido incubado en penicilina $G$ que le incapacita para producir estreptolisina S. ${ }^{5}$ Está contraindicado su uso en pacientes alérgicos a b-lactámicos por riesgo de anafilaxia. ${ }^{6}$ Así mismo, el uso de antibioticoterapia concomitante con el momento de actuación del OK-432 puede hacer disminuir su eficacia. ${ }^{4}$ Ogita y cols. ${ }^{9}$ describieron su mecanismo de acción: un aumento en el linfangioma de células inflamatorias (especialmente neutrófilos y macrófagos), de células natural killer (CD56+), de linfocitos T (CD3+) y un aumento de TNF e IL-6 que incrementa la permeabilidad del endotelio del linfangioma, provocando su drenaje linfático y consecuente vaciamiento de los espacios quísticos con colapso y esclerosis circunscrita a las paredes de la lesión. 10,11

\section{Introduction}

Lymphangioma is a congenital malformation of the lymphatic system that occasionally is acquired after traumatic, infectious, iatrogenic or neoplastic action. 1,2 It occurs as a slow-growing benign mass of soft consistency that usually is asymptomatic. It can cause cosmetic and functional problems like dysphagia and dyspnea, particularly when it increases in size quickly due to infection or bleeding when vascular lesions are present. There are no differences between sexes. 1,2,4-6 Morbidity and mortality are related to the size and young age of the patient. ${ }^{2}$ Up to $90 \%$ of lymphangiomas are diagnosed before the age of 2 years and up to $50 \%$ at birth. ${ }^{4}$ The most frequent location of lymphangioma is the cervical region (75\%) and within this area, the posterior triangle.7 Other locations follow, e.g., the submentonian region, tongue, oropharynx and parotid cell.

Lymphangioma is classified as capillary, cavernous, and cystic; different forms can coexist in same lymphangioma. The location, structure, and consistency of the surrounding tissues can condition different histologic types. Cystic lymphangioma consists of cysts delimited by a layer of endothelium. It occurs in areas of lax tissue and numerous fascias, such as the cervical region. 1,2 It can be subclassified, in turn, by size. We define lesions with cysts larger than $2 \mathrm{~cm}$ as macrocystic and lesions con cysts smaller than $2 \mathrm{~cm}$ as microcystic. Mixed lymphangiomas that are predominantly macrocystic or microcystic exist.

Anatomically, the tumors are cavities filled with lymphatic fluid, delimited by vascular endothelium, and connected with the peripheral lymphatic system as a result of erroneous embryogenesis. ${ }^{8}$

The diagnosis is based on clinical manifestations and imaging techniques. MRI is the technique that yields the best definition, extension of the lesion, and view of neighboring structures. Doppler sonography is useful for differentiating lymphangioma from vascular malformations or mixed lymphangiomas by the presence of vascular flow. MRI may not distinguish lymphangioma from venous malformations, which is why the use of contrast can help in the diagnosis of these cases. ${ }^{4}$ FNAB can also be used as a diagnostic method. ${ }^{1}$ The differential diagnosis includes branchial cyst, thyroglossal cyst, laryngocele, thyroid mass, lipoma, and vascular malformations. Treatment can be surgical excision or sclerosis of the lesion using sclerosing agents. OK-432, also known as Picibanil, is noteworthy among them. It is a low-virulence, lyophilyzed compound obtained from Streptococcus pyogenes group A bacteria of human origin. It has been incubated in penicillin $\mathrm{G}$, which incapacitates it to produce streptolysin S. ${ }^{5}$ Its use in patients allergic to b-lactams is contraindicated due to the risk of anaphylaxis. ${ }^{6}$ The use of concomitant antibiotic therapy at the time of OK-432 administration can diminish its effectiveness. ${ }^{4}$ Ogita et al..$^{9}$ described its mechanism of action: increased number of inflammatory cells (especially neutrophils and macrophages), natural 


\section{Material y Método}

Reportamos un caso clínico de un varón de 16 años que se presenta en la consulta con una masa laterocervical derecha, totalmente asintomática y consistencia blanda, de $10 \times 6 \mathrm{~cm}$ de tamaño con el evidente compromiso estético (Fig. 1). Según refiere el paciente, le apareció a los 7 años, de forma más o menos rápida y como resultado de un fuerte traumatismo en dicha región. Le realizamos una RM que informaba de linfangioma cervical macroquístico (Figs. 2 y 3). Con este diagnóstico se decide tratamiento con OK-432. En quirófano, bajo sedación con propofol y sin ecografía guiada por lo evidente del linfangioma, administramos una sola dosis de 0,2 mg de OK-432 disuelta en $20 \mathrm{ml}$ de suero fisiológico. Puncionamos el linfangioma, previa desinfección de la piel con povidona yodada. Aspiramos $20 \mathrm{ml}$ de su contenido y a continuación, sin retirar la aguja o el catéter, inyectamos $20 \mathrm{ml}$ de suero fisiológico con 0,2 mg de OK-432 disueltos. No hubo ninguna complicación intraoperatoria. Al paciente se le administró paracetamol profiláctico que evitó la fiebre, pero no así el dolor e inflamación local que llegó a medir 14 × $10 \mathrm{~cm}$, e imposibilitaba la movilidad del cuello. La vía aérea fue permeable en todo momento, por lo que no fue necesaria la realización de traqueotomía. Durante el ingreso se le administró una perfusión continua de analgesia (3 viales de metamizol en 500 cc suero glucosado a $21 \mathrm{ml} / \mathrm{h}$, con tramadol en la perfusión a demanda del paciente). Tras el control del dolor se dio de alta a los 7 días del ingreso.

\section{Resultados}

A los 23 días de la inyección del OK432 el paciente percibió franca reducción del linfangioma, desapareciendo clínicamente en los 3 días siguientes. $\mathrm{A}$ las 16 semanas post-inyección se realizó una RM de control que informó de linfangioma cervical derecho de $6 \times 2 \mathrm{~cm}$ (Figs. 4 y 5), pasando clínicamente desapercibido (Fig. 6), por lo que, junta-

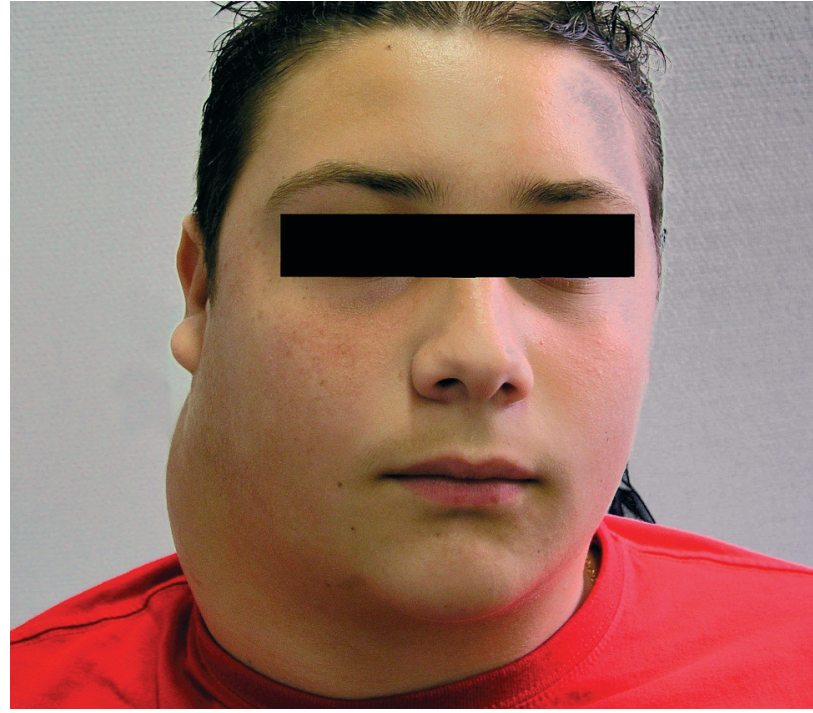

Figura 1. Paciente antes del tratamiento con OK-432.

Figure 1. Patient before treatment with OK-432.

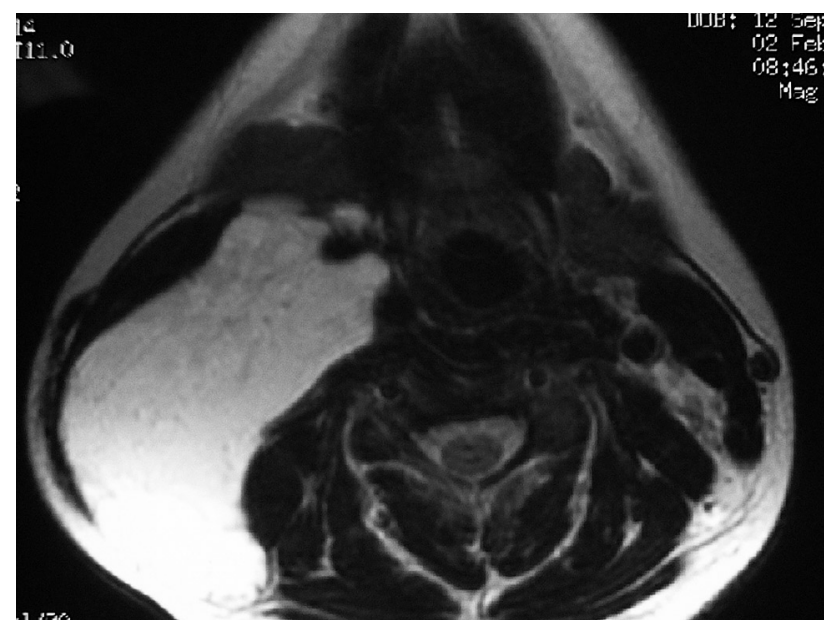

Figura 2. RM. Corte coronal antes del tratamiento con OK-432. Figure 2. MRI. Coronal slice before treatment with OK-432.

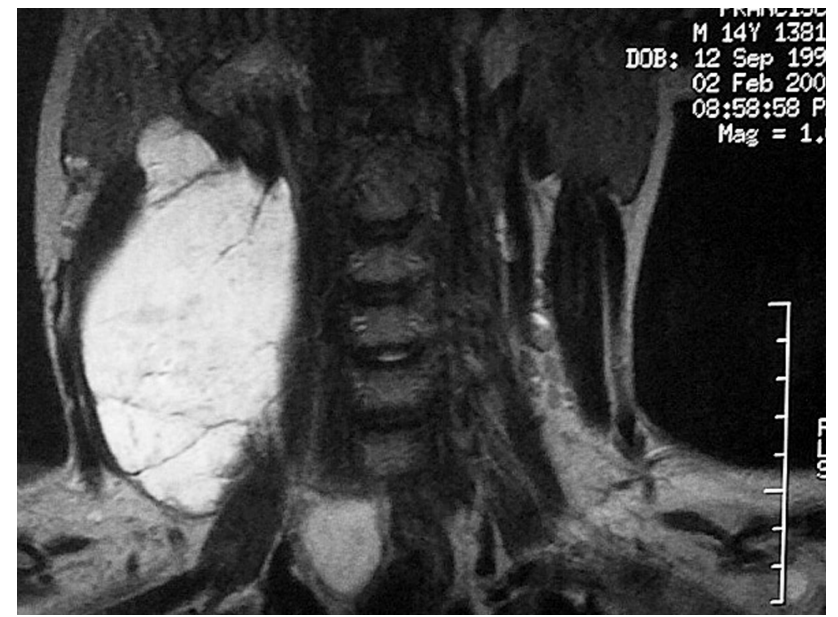

Figura 3. RM. Corte longitudinal antes del tratamiento con OK-432. Figure 3. MRI. Longitudinal slice before treatment with OK-432. killer cells (CD56+) and lymphocytes $T(C D 3+)$, and an increase in TNF and IL-6 that enhances the endothelial permeability of the lymphangioma, producing lymphatic drainage, emptying and collapse of cystic spaces, and sclerosis confined to the walls of the lesion. ${ }^{10,11}$

\section{Material and Method}

We report the clinical case of a 16-year-old male who came to the clinic with a right laterocervical mass that was totally asymptomatic, of soft consistency, $10 \times 6 \mathrm{~cm}$ in size, and had an evident esthetic impact (Fig. 1). As referred by the patient, the mass appeared fairly rapidly when he was 7 years old as a result of intense trauma to the region. MRI revealed macrocystic cervical lymphangioma (Figs. 2 and 3). The decision to use OK-432 treatment was based on this diagnosis. In the operating room, under propofol sedation and without guided ultrasonography due to the size of the lymphangioma, a single dose of $0.2 \mathrm{mg}$ of OK-432 dissolved in $20 \mathrm{ml}$ saline solution was administered. We inserted a needle in the lymphangioma after disinfecting the skin with iodinated povidone. We extracted $20 \mathrm{ml}$ of the content and, without removing the needle or catheter, injected 20 $\mathrm{ml}$ saline solution with 0.2 mg OK-432 dissolved. There were no intraoperative complications. The patient was administered prophylactic paracetamol, which prevented fever, but not pain and local inflammation. The tumor swelled to $14 \times 10 \mathrm{~cm}$ 
mente con el paciente, desestimamos una nueva inyección de OK-432. Tras un seguimiento de 42 semanas desde el tratamiento del linfangioma, el paciente no tiene signos clínicos del linfangioma y hace una vida totalmente normal.

\section{Discusión}

El tratamiento clásico del linfangioma ha sido la cirugía. ${ }^{3}$ En contraposición ha habido diferentes agentes con acción esclerosante tales como esteroides, dextrosa, tetraciclina, etanol y bleomicina entre otros, con el inconveniente de esclerosar más allá de las paredes del linfangioma, como en el caso de la bleomicina que causa fibrosis pulmonar. La ventaja la encontramos a la hora de evitar lesiones vasculares, nerviosas y de estructuras vitales adyacentes que se pueden producir con la cirugía.

En 1987, Ogita y cols. ${ }^{12}$ publicó el primer estudio en pacientes con linfangioma, a los que se le inyectó un agente utilizado anteriormente como immunomodulador en procesos tumorales, llamado OK-432 con el que se demostró acción esclerosante con ausencia de fibrosis perilesiy cols. ${ }^{12}$, la dosis máxima de OK-432 para el linfangioma es de 0,2 mg disueltos en $20 \mathrm{ml}$ de suero fisiológico. El tiempo de respuesta medio a la primera inyección oscila entre las 2-6 semanas. No hay descrita una edad mínima ni máxima para la aplicación de este tratamiento. La inyección de OK-432 se administra mediante anestesia general en niños y sedación en adultos sin que sea necesaria de forma sistemática la punción mediante ecografía guiada. Los efectos adversos más comúnmente descritos son la fiebre, eritema, dolor e inflamación local, que en muy pocos casos descritos requiere la realización de traqueotomía. La respuesta global difiere según la clasificación del linfangioma. El macroquístico y mixto responden mucho mejor que el microquístico o combinado con lesiones vasculares y no tiene efecto sobre los linfangiomas cavernosos o capilares.4,5,6,13. Esto se puede explicar por el mayor número de comunicaciones existentes entre los espacios intralesionales de los linfangiomas macroquísticos, que mejoran la difusión del agente esclerosante dentro de la lesión. ${ }^{5}$

La recidiva del linfangioma tras el tratamiento con OK-432 según Luzzatto y cols. ${ }^{6}$ es del $11 \%$. La regresión espontánea del linfangioma está descrita hasta el $6 \%$, dependiendo de las series. ${ }^{2,4,6}$

La cirugía previa al tratamiento con OK-432 disminuye la tasa de éxito por el mayor número de inyecciones necesarias para con-

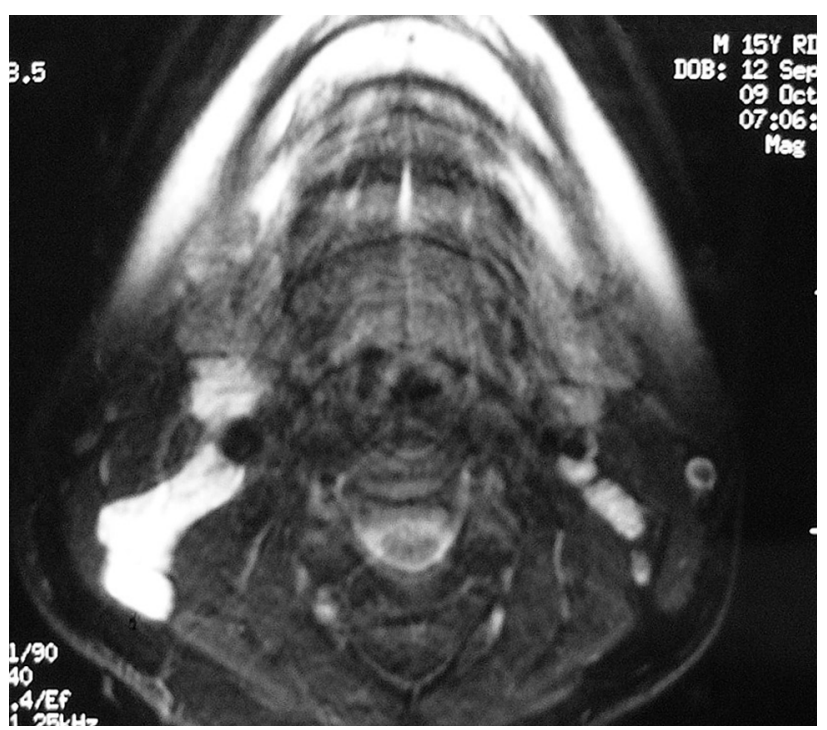

and impeded neck movement. The airway remained patent at all times, so tracheotomy did not have to be performed. During admission, continuous analgesic perfusion was administered ( 3 vials of metamizole in 500 cc glucose solution infused at $21 \mathrm{ml} / \mathrm{h}$; tramadole was added to the perfusion as demanded by the patient). The patient was released once the pain was controlled, 7 days after admission.
Figura 4. RM. Corte coronal. 16 semanas post-OK-432.

Figure 4. MRI. Coronal slice. 16 weeks post-OK-432.

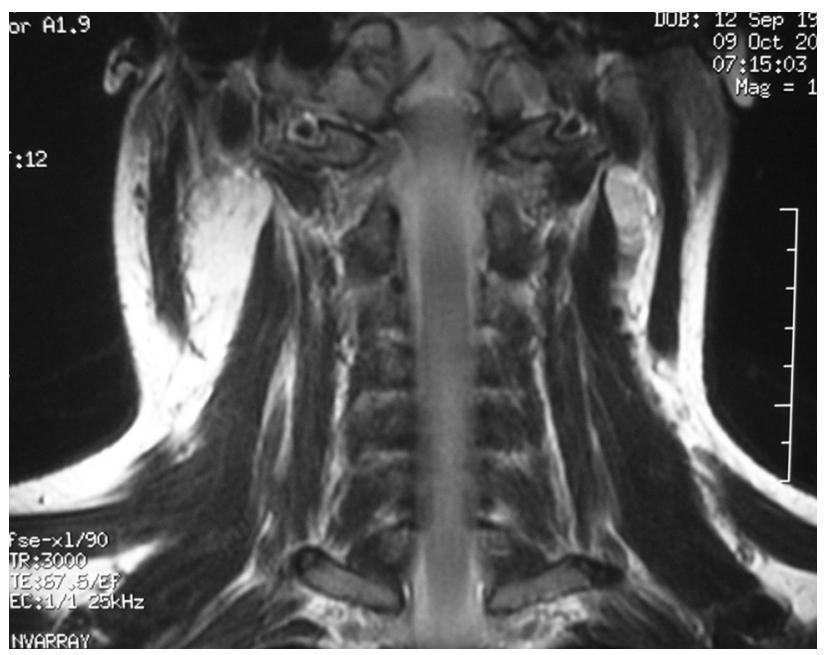

Figura 5. RM. Corte longitudinal. 16 semanas post-OK-432. Figure 5. MRI. Longitudinal slice. 16 weeks post-OK-432.

\section{Results}

Twenty-three days after injecting OK-432, the patient experienced frank reduction in the lymphangioma, which disappeared clinically in the next 3 days. Sixteen weeks post-injection, a follow-up MRI disclosed a right cervical lymphangioma of $6 \times 2 \mathrm{~cm}$ (Figs. 4 and 5), which had passed unnoticed clinically (Photograph 6). We ruled out a new injection of OK-432 with the patient. After a post-treatment follow-up of 42 weeks, the patient showed no clinical signs of lymphangioma and had a totally normal life.

\section{Discussion}

The classic treatment of lymphangioma is surgery. ${ }^{3}$ Alternatively, different sclerosing agents have been used, including steroids, dextrose, tetracycline, ethanol, and bleomycin. These agents have the disadvantage of producing sclerosis outside the walls of the lymphangioma, as in the case of bleomycin, which causes pulmonary fibrosis. The advantage is that the lesions to blood vessels, nerves, and adjacent vital structures that can occur with surgery are avoided.

In 1987, Ogita et al. ${ }^{12}$ published the first study in patients with lymphangioma in which an agent used previously as an immunomodulator in tumoral processes, called OK-432, was injected. It was shown to have a sclerosing action with- 
seguir la curación. 4,5 La cirugía, a menudo es compleja y con frecuencia, no consigue la extirpación completa del tumor, hay tasas más altas de recurrencias, de complicaciones y de enfermedad sintomática persistente..$^{2,3}$

Por ello, y por la ausencia de esclerosis más allá de las paredes del linfangioma, el OK-432 se ha convertido en el primer escalón terapéutico para el tratamiento del linfangioma, reservando la cirugía cuando es necesaria una rápida mejoría del paciente ${ }^{14} \mathrm{o}$ bien la esclerosis de la lesión mediante OK-432 no es efectiva. Según Luzzatto y cols. ${ }^{6}$ no es efectiva cuando se administran 3 inyecciones con un intervalo de 12 semanas de una a otra sin mejoría alguna, aunque en las diferentes series encontramos hasta 7 inyecciones en

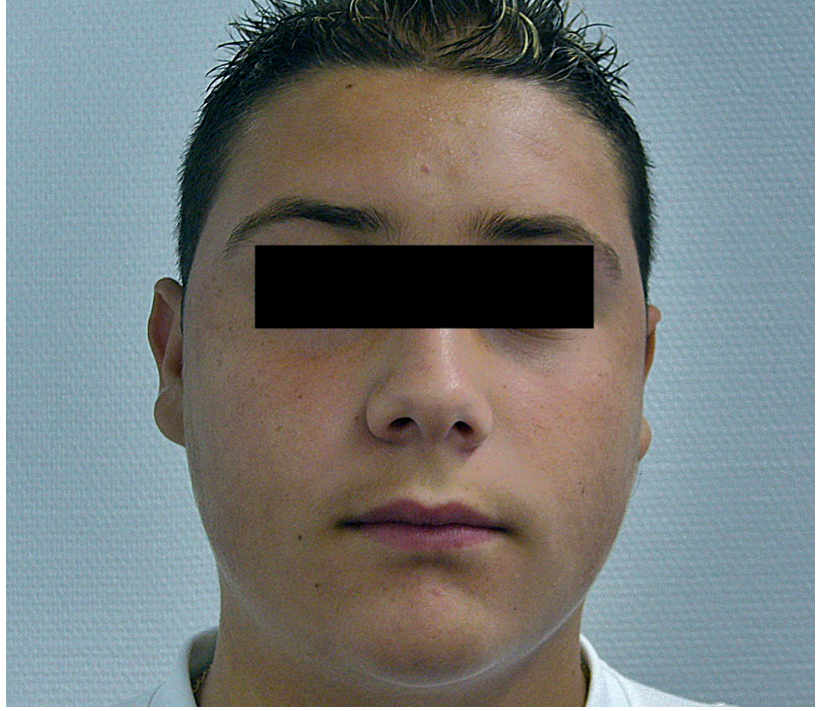

Figura 6. Paciente 42 semanas post-tratamiento OK-432. Figure 6. Patient 42 weeks post-OK-432. out perilesional fibrosis. 10,11 As reported by Ogita et al., ${ }^{12}$ the maximum dose of $\mathrm{OK}$ 432 for lymphangioma is $0.2 \mathrm{mg}$ dissolved in $20 \mathrm{ml}$ saline solution. Mean response time to the first injection is 2-6 weeks. No minimum or maximum age for using this treatment has been described. OK-432 is injected under general anesthesia in children and with sedation in adults. Insertion of the needle under ultrasonographic guidance is not required systematically. The adverse effects most commonly reported are fever, erythema, pain, and local inflammation, which in very few cases require tracheotomy. The overall response differs in accordance with the classification of the lymphangioma. Macrocystic and mixed lymphangiomas respond far better than microcystic lymphangiomas or mixed vascular lesions. There is no effect on cavernous or capillary lymphangiomas. ${ }^{4-}$ 6,13 This may be explained by the larger number of communications existing between the intralesional spaces of macrocystic lymphangiomas, which improves the diffusion of the sclerosing agent in the lesion. ${ }^{5}$

Recurrence of lymphangioma after OK-432 treatment, according to Luzzatto et al., ${ }^{6}$ is $11 \%$. Spontaneous lymphangioma regression has been reported in up to $6 \%$, depending on the series. 2,4,6

Surgery prior to OK-432 treatment diminishes the success rate due to the larger number of injections necessary to achieve cure. ${ }^{4,5}$ Surgery often is complex and frequently does not achieve complete tumor excision, resulting in higher rates of recurrence, complications, and persistent symptomatic disease. ${ }^{2,3}$

For that reason, and due to the absence of sclerosing action outside the walls of the lymphangioma, OK-432 has become the first-line therapy for lymphangioma. Surgery is reserved for cases that require rapid improvement of the patient ${ }^{14}$ or when OK-432-induced sclerosis of the lesion is ineffective. According to Luzzatto et al. ${ }^{6}$ OK-432 can be considered ineffective when 3 injections spaced by 12-week intervals are administered without improvement, although up to 7 injections in same lymphangioma are given in some series. 4,5

11. Luzzatto C, Midrio P, Tchaprassian Z, Guglielmi M. Sclerosing treatment of lymphangiomas with OK-432. Arch Dis Child 2000;82:316-18.

12. Ogita S, Tsuto T, Tokiwa K, Takahashi T. Intracystic injection of OK-432: a new sclerosing therapy for cystic hygroma in children. B J Surg 1987;74:690-1.

13. Ogita S, Tsuto T, Nakamura K, Deguchi E, Iwai N. OK-432 therapy in 64 patients with lymphangioma. J Pediatr Surg 1994;29:784-5.

14. Sichel JY, Udassin R, Gozal D, Koplewitz BZ, Dano I, Eliashar R. OK-432 therapy for cervical lymphangioma. Laryngoscope 2004;114:1805-9. 